University of Michigan Law School

University of Michigan Law School Scholarship Repository

Articles

Faculty Scholarship

1917

\title{
Liability of Public Officer for the Loss of Private Funds Entrusted to His Keeping
}

W. Gordon Stoner

University of Michigan Law School

Available at: https://repository.law.umich.edu/articles/1359

Follow this and additional works at: https://repository.law.umich.edu/articles

Part of the Legal Remedies Commons, State and Local Government Law Commons, and the Torts Commons

\section{Recommended Citation}

Stoner, W. Gordon. "Liability of Public Officer for the Loss of Private Funds Entrusted to His Keeping." Mich. L. Rev. 16 (1917): 114-5.

This Response or Comment is brought to you for free and open access by the Faculty Scholarship at University of Michigan Law School Scholarship Repository. It has been accepted for inclusion in Articles by an authorized administrator of University of Michigan Law School Scholarship Repository.

For more information, please contact mlaw.repository@umich.edu. 
Liabinity of Public Officer for the Loss of Private Funds Entrusted To HIs KEEPING.-There is much contrariety of decision concerning the liability of public officers for the loss of funds with which they have been entrusted. A recent case illustrates some of the more important phases of the law of such a situation. People for use of Hoyt et al. v. McGrath et al. (III. I9I7), II7 N. E. 74. In this case the public brought an action of debt on the official bond of the clerk of court for the use of Hoyt and others. Usees had tendered into court a sum of money which the clerk took under the court's order to receive and hold it, but refused to pay it over to the usees as directed by a later order of the court, claiming the money had been received by him in his individual capacity and had been lost without his fault by the failure of the bank in which it had been deposited. Held, that as a public officer is liable as an insurer for private funds received by virtue of his office, the failure of the clerk to pay over the money in question constituted a breach of his official statutory bond.

The public officer, on the theory of the existence of a debtor-creditor relation between the public corporation and the officer with respect to the public funds in his possession, on the ground of public policy, because the loss rocurs by reason of the unauthorized acts of the officer, as for example, the unauthorized deposit of public funds in a bank which later fails, or on account of the language of the bond or of the statute defining the duties of the officer, is generally held absolutely liable as an insurer for the safety of 
public funds entrusted to him. Fairchild v. Hedges, I4 Wash. II7; County of Mecklenburg v. Beales, III Va. 69I, 36 L. R. A. (N. S.) 285; Northern Pacific Ry. Co. v. Owens, 86 Minn. 188; State v. Bobleter, 83 Minn. 479; Estate of Ramsay v. People, I97 Ill. 572, 90 Am. St. Rep. 177. To this rule of liability exceptions have generally been made of cases where the funds have been lost without the officer's fault, solely by act of God or the public enemy, United States v. Thontas, I5 Wall. 337 (act of public enemy); Thompson v. Bonrd of Trustees, 30 Ill. 99 (dicta); State v. Lee, 72 Miss. 28r (dicta); Maloy v. Board of County Commissioners, to N. Mex. 638. A few cases refuse to make even these exceptions. Havens v. Lathene, 75 N. Car. 505; State v. Walsen, 17 Colo. 170. In some states, however, the rule is established that the officer having custody of public moneys is relieved from responsibility for the loss of funds which he has exercised due care and diligence to preserve. Livingston v. Woods, 20 Mont. 9I ; State v. Copeland, 96 Tenn. 296; State v. Gramm, 7 Wyo. 329. This is clearly the minority rule. The case noted is of especial interest because the funds in question were private, not public, funds. Some few courts have drawn a distinction in cases of this sort between public and private funds, and hold the officer liable as a bailee for hire in event of the loss of funds of the latter class. Gartley v. People, 28 Colo. 227 ; People v. Faulkner, 107 N. Y. 477. The reason sometimes offered for such distinction is that as the public corporation is not liable for the loss of funds where there is no negligence, so the officer, the agent of the public corporation, ought not to be. It is frequently unsafe to apply the analogy of agency in cases involving officers. Officers are frequently liable for injury or loss when the public corporation which he serves is not liable. So the reason offered is not convincing. In People v. Faulkner, supra, the reason suggested for the distinction between public and private funds is the greater degree of watchfulness and scrutiny which the owner of private funds gives to the acts of an officer who has custody of his funds. This reason is not very convincing, and it seems that the attempted distinction might well be disregarded and the officer held to the same liability for loss of private funds and for the loss of those of the public. In the great mass of cases involving liability of the officer for loss of funds without his fault the distinction has not been raised. Shaw v. Bauman, 34 Ohio St. 25; Smith v. Patton, I3I N. Car. 396; Phillips v. Lamar, $27 \mathrm{Ga} .228$.

G. S. 